\title{
PENGARUH SUBJECTIVE WELL BEING DIMASA PANDEMI COVID-19 TERHADAP HASIL BELAJAR MATEMATIKA SISWA SEKOLAH DASAR
}

\author{
Enik Maryanti ${ }^{1}$, Muhammad Ilyas ${ }^{2}$, Nurdin ${ }^{3}$ \\ Universitas Cokroaminoto Palopo ${ }^{1,2}$, Universitas Muhammadiyah enrekang ${ }^{3}$ \\ Email: enikmaryanti1981@gmail.com ${ }^{1}$
}

\begin{abstract}
Abstrak. Pandemic covid 19 mempengaruhi sebagian besar aspek dalam dunia Pendidikan termasuk pendidikan dasar. Salah satu aspek yang terdampak dari perubahan ini adalah hasil belajar. Hasil belajar dimasa pandemic ini dipengaruhi beberapa faktor di antaranya Subjective Well Being. Penelitian ini bertujuan untuk mengetahui gambaran Subjective Well Being dan hasil belajar matematika siswa Sekolah Dasar dimasa pandemi Covid-19 dan untuk mengetahui pengaruh Subjective Well Being terhadap Hasil Belajar Matematika siswa Sekolah Dasar di masa pandemik Covid-19. Jenis penelitian ini adalah ex-post facto. Pada penelitian ini yang menjadi populasi adalah seluruh Siswa Sekolah Dasar yang terdapat di Kecamatan Malili, Kabupaten Luwu Timur, Porvinsi Sulawesi Selatan dan sampelnya 360 orang siswa kelas IV SD dengan cara Purposive sampling. Data Subjective Well Being diperoleh menggunakan angket dan hasil belajar matematika menggunakan tes. Analisis data yang digunakan adalah analisis deskriptif untuk mendeskripsikan karakteristik masing-masing variabel dan analisis inferensial untuk menguji hipotesis penelitian digunakan uji regresi. Hasil penelitian menunjukkan bahwa Subjective Well Being siswa Sekolah Dasar dimasa pandemi Covid-19 berada pada kategori sedang dan Hasil Belajar Matematika siswa Sekolah Dasar dimasa pandemi Covid-19 berada pada kategori sedang. Terdapat pengaruh Subjective Well Being terhadap Hasil Belajar Matematika siswa Sekolah Dasar dimasa pandemi Covid19.
\end{abstract}

\section{Kata kunci: Subjective Well Being, Hasil Belajar Matematika}

\begin{abstract}
The COVID-19 pandemic affects most aspects of the world of education, including basic education. One aspect that brings about this change is learning outcomes. Learning outcomes during this pandemic are influenced by several factors, including Subjective Well Being. This study aims to determine the description of Subjective Well Being and elementary school mathematics learning outcomes during the Covid-19 pandemic and to determine the effect of Subjective Well Being on Primary School Mathematics Learning Outcomes during the Covid-19 pandemic. This type of research is ex-post facto. In this study, the population was all elementary school students in Malili District, East Luwu Regency, South Sulawesi Province and the sample was 360 fourth grade elementary school students by purposive sampling. Subjective Well Being data was obtained using a questionnaire and mathematics learning outcomes using a test. Analysis of the data used is descriptive analysis to describe the characteristics of each variable and inferential analysis to test the hypothesis used regression test. The results showed that the Subjective Welfare of Elementary School students during the Covid-19 pandemic was in the medium category and Mathematics Learning Outcomes of Elementary School students during the Covid-19 pandemic were in the medium category. There is a subjective well-being influence on elementary school students' math results during the Covid-19 pandemic.
\end{abstract}

\section{Keywords: Subjective Well Being, Mathematics Achievement}

\section{A. Pendahuluan}

Pemberlakuan study from home membawa dua akibat secara bersamaan. Pertama, kurangnya kontrol guru terhadap siswa yang belajar dari rumah. Berbeda pada saat sebelum wabah corona menyerang negara kita Indonesia, banyaknya pertemuan antara peserta didik dan guru tentunya akan minim. Kurangnya pengawan guru akan membuat beberapa siswa merasa bebas memilih tempat untuk belajar. Kedua, waktu yang sempit. Pemberitahuan agar stay at home serentak akan menyebabkan banyak waktu yang terbuang percuma bagi para peserta didik. Pada awalnya setiap siswa belajar disekolah mendapatkan waktu kosong lima atau enam 
jam, maka setelah adanya pandemi virus korona dan pemberlakuan belajar di rumah, waktu kosong mereka akan bertambah empat atau lima jam (Hudaifah, 2020).

Perubahan pola belajar yang terjadi kepada siswa akan berdampak pada hasil belajar matematika siswa. Hasil penelitian Fauzi \& Khusuma, (2020) menunjukkan bahwa pandemi COVID-19 berdampak besar dan berubah dalam proses Pendidikan. Sebagian besar guru menganggap bahwa pembelajaran dimasa covid 19 tidak efektif karena banyak masalah ditemukan, misalnya 1) ketersediaan fasilitas, 2) penggunaan jaringan dan internet, 3) perencanaan, pelaksanaan, dan evaluasi pembelajaran, dan 4) kerjasama dengan orang tua. Selain dalam pembuatan bahan ajar, sebagian besar guru memodifikasi materi dari berbagai sumber dan konten yang sering dibuat adalah audio visual.

Saat ini Psychological Well-being memiliki peran yang sangat krusial bagi peserta didik karena well-being adalah salah satu faktor yang mempengaruhi hasil pembelajaran dan perkembangan peserta didik (Froh, Franklin, \& Templeton, 2009). Peserta didik dengan psychological well-being yang rendah ditandai dengan rendahnya dimensi penerimaan diri remaja. Penerimaan diri yang kurang adalah sumber utama yang menyebabkan siswa sulit untuk membuat tindakan, prestasi rendah, tidak berani dan kurang percaya diri untuk bersaing dengan siswa lain. Artinya, rendahnya penerimaan diri pada peserta didik dapat bepengaruh negatif terhadap perkembangan diri dan aktualisasi potensi peserta didik. Meskipun beberapa penelitian berfokus pada remaja, namun tidak menutup kemungkinan Subjective Well Being juga dimiliki oleh anak pada tingkat sekolah dasar. Alasannya adalah psikologi siswa SD lebih cenderung mudah dipengaruhi dibandingkan dengan remaja (Silvia, 2018).

Diener (Ramadhani, 2017) menyatakan bahwa Subjective Well Being merupakan hasil penilaian individu terhadap kehidupan yang dilaluinya baik secara kognitif maupun afektif. Untuk mengevaluasi Subjective Well Being pada aspek kognitif yaitu berupa kepuasan hidup maupun kepuasan terhadap wilayah penting dalam hidup individu, serta untuk mengevaluasi komponen afektif melibatkan efek positif dan efek negatif yang dirasakan.

OECD, (2013) memperlihatkan tiga elemen dari Subjective Well Being diantaranya:

a. Evaluasi kehidupan - penilaian reflektif tentang kehidupan seseorang atau beberapa aspek tertentu darinya.

b. Mempengaruhi - perasaan atau keadaan emosional seseorang, biasanya diukur dengan mengacu pada titik waktu tertentu.

c. Eudaimonia - rasa makna dan tujuan dalam hidup, atau fungsi psikologis yang baik.

Subjektif Well Being adalah suatu perasaan psikologis yang tidak peduli dengan apa yang orang miliki atau apa yang terjadi pada orang tersebut, tetapi bagaimana mereka berpikir dan merasakan tentang apa yang mereka miliki dan apa yang terjadi pada mereka. Studi tentang Subjective Well Being membuat perbedaan antara kondisi obyektif kehidupan seseorang dan evaluasi subjektif dan perasaan orang tersebut tentang hidupnya (Maddux, 2018).

Menurut Compton (dalam Indriana, 2012), Subjective Well Being mempengaruhi tinggi rendahnya nilai kebahagiaan dan kepuasan dalam kehidupan individu. Menurut Compton (2000), Subjective Well Being mempengaruhi tinggi rendahnya nilai kebahagiaan dan kepuasan dalam kehidupan individu, diantaranya:

1. Harga Diri (Self Esteem)

Self Esteem yang positif merupakan variabel yang terpenting dalam Subjective Well Being karena evaluasi terhadap diri akan mempengaruhi bagaimana seseorang menilai kepuasan dalam hidup dan kebahagiaan yang mereka rasakan. Seseorang yang memiliki Self Esteem rendah cenderung tidak akan merasa puas dengan hidupnya dan tidak akan merasa bahagia. Self Esteem yang positif berasosiasi dengan fungsi adaptif dalam setiap aspek kehidupan. 
2. Arti kontrol kesadaran

Kontrol pribadi merupakan keyakinan individu bahwa ia dapat memaksimalkan hasil yang bagus dan atau meminimalkan hasil yang jelek. Dengan keyakinan ini maka seseorang dapat mempengaruhi peristiwa - peristiwa yang terjadi dalam hidupnya, memilih hasil yang diinginkan, menghadapi konsekuensi dari pilihannya, dan memahami serta menginterpretasikan hasil dari pilihannya. Jadi kontrol pribadi dapat membantu seseorang untuk mewujudkan apa yang diinginkannya, yang kemudian dapat membawa kepuasan akan hidupnya.

3. Ekstrovert

Individu dengan kepribadian ekstrovert (sifat terbuka) akan tertarik pada hal hal yang terjadi di luar dirinya, seperti lingkungan fisik dan sosialnya. Kepribadian ekstrovert secara signifikan akan memprediksi terjadinya kesejahteraan individual. Orang-orang dengan kepribadian ekstrovert biasanya memiliki teman dan relasi sosial yang lebih banyak, merekapun memiliki sensitifitas yang lebih besar mengenai penghargaan positif pada orang lain.

4. Optimis

Orang yang optimis mengenai masa depan merasa lebih bahagia dan puas dengan kehidupannya. Individu yang mengevaluasi dirinya dalam cara yang positif, akan memiliki kontrol yang baik terhadap hidupnya, sehingga memiiki impian dan harapan yang positif tentnag masa depan.

5. Hubungan positif

Hubungan yang positif akan tercipta bila adanya dukungan sosial dan keintiman emosional. Hubungan yang didalamnya ada dukungan dan keintiman akan membuat individu mampu mengembangkan harga diri, meminimalkan masalah-masalah psikologis, kemampuan pemecahan masalah yang adaptif, dan membuat individu menjadi sehat secara fisik.

6. Makna dan tujuan hidup

Memiliki makna dan tujuan dalam hidup merupakan faktor penting dari Subjective Well Being, karena siswa yang demikian akan memiliki rasa puas atau Bahagia dalam kehidupanya.

Berdasarkan uraian di atas maka dapat dikatakan bahwa Subjective Well Being sangat baik dijadikan salah satu komponen dalam pembelajaran dikelas. Sesuai dengan pendapat dari Shoshani \& Steinmetz (2013) bahwa pelibatan Subjective Well Being sebagai bagian integral dari kurikulum sekolah merupakan suatu yang sangat dibutuhkan di dunia pendidikan.

Subjective Well Being pada siswa di Sekolah dapat menjadi prediksi ketika mereka memasuki fase akhir atau fase dewasa, apakah mereka akan mampu mencapai keberhasilan, terlibat secara produktif dalam kehidupan masyarakat, atau justru mengalami tekanan dan terasing dari kehidupan sosial Roeser (Ramadhani, 2017). Fluktuasi dari Subjective Well Being juga berhubungan dengan aspek penilaian yang dilakukan dalam mengevaluasi kehidupan siswa (Ramadhani, 2017).

Berdasarkan kajian diatas maka tujuan penelitian ini adalah untuk mengetahui Pengaruh Subjective Well Being terhadap Hasil Belajar Matematika Siswa Sekolah Dasar Dimasa Pandemi Covid-19

\section{B. Metode Penelitian}

Jenis penelitian yang digunakan adalah ex post facto. Penelitian ex post facto adalah suatu penelitian yang dilakukan untuk meneliti peristiwa yang telah terjadi dan kemudian melihat ke belakang untuk mengetahui faktor-faktor yang dapat menimbulkan kejadian tersebut. Keterikatan antar variabel bebas yakni (Subjective Well Being) terhadap variabel terikat (Hasil Belajar Matematika) telah terjadi secara alami. 
Pada penelitian ini yang menjadi populasi adalah seluruh Siswa Sekolah Dasar yang terdapat di Kecamatan Malili, Kabupaten Luwu Timur, Porvinsi Sulawesi Selatan. Kecamatan Malili, Kabupaten Luwu timur memiliki 23 Sekolah pada jenjang Sekolah Dasar. Sekolahsekolah tersebut terdiri atas sekolah Negeri dan Sekolah Swasta. Berdasarkan data Tim Dapodikbud pada semester data 2019/2020-2 pada laman http://sekolah.data.kemdikbud.go.id diperoleh data sekolah dan jumlah siswa.

Instrumen peneltian yang akan digunakan dalam penelitian ini adalah angket Angket Subjective Well Being, angket ini di adaptasi dari Diener, E., Wirtz, D., Tov, W., Kim-Prieto, C., Choi, D., Oishi, S., \& Biswas-Diener, R. (2009). New measures of well-being: Flourishing and positive and negative feelings. Social Indicators Research, 39, 247-266.

\section{Tabel 1. Kisi-Kisi Angket Subjective Well Being}

\begin{tabular}{lc}
\hline Indikator & Jumlah Item Pernyataan \\
\hline Memiliki perasaan puas dengan kehidupannya & 8 \\
secara keseluruhan & \\
Terpenuhinya kebutuhan, keinginan dan harapan & 6 \\
dalam hidup & 4 \\
Memiliki sikap optimis & 10 \\
Merasa bahagia & 2 \\
Aktif & 30 \\
\hline Jumlah & \\
\hline
\end{tabular}

Angket tersebut diadaptasi sesuai dengan masa pandemic covid-19 dimana Sebagian besar siswa belajar dari rumah. Angket ini memiliki 4 opsi respon yakni Sangat Setuju, Setuju, Tidak Setuju, dan Sangat Tidak Setuju. Angket akan dibuat dengan menggunakan google form dan disebar kepada responden.

Tes Hasil Belajar pada penelitian ini dibuat dengan mengambil indikator dari materi kelas IV SD semester Genap.

\section{Tabel 2. Tes Hasil Belajar}

\begin{tabular}{|c|c|}
\hline Indikator & Jumla Soal \\
\hline $\begin{array}{l}\text { Menyajikan penyelesaian masalah yang terkait dengan } \\
\text { pecahan senilai dengan mengalikan atau membagi } \\
\text { pembilang dan penyebut dengan bilangan yang sama }\end{array}$ & 2 \\
\hline $\begin{array}{l}\text { Menyelesaikan masalah yang berkaitan dengan pecahan } \\
\text { biasa, pecahan campuran, } 83 \text { andemi, dan persen }\end{array}$ & 2 \\
\hline $\begin{array}{l}\text { Menyajikan penyelesaian masalah yang berkaitan dengan } \\
\text { pecahan biasa, }\end{array}$ & 2 \\
\hline $\begin{array}{l}\text { Menyelesaikan masalah yang terkait dengan FPB dan } \\
\text { KPK }\end{array}$ & 2 \\
\hline $\begin{array}{l}\text { Menyajikan penyelesaian masalah } \\
\text { FPB dan KPK }\end{array}$ & 2 \\
\hline
\end{tabular}

Analisis data yang digunakan untuk mengetahui pengaruh variabel X (Subjective Well Being siswa dan Self Awareness siswa) terhadap variabel Y (Hasil Belajar Matematika Siswa) adalah dengan acuan skor mean hipotetik, dan deviasi standar. Adapun Kriterianya sebagai berikut 
Tabel 3. Kategori Subjective Well Being dan Self Awareness

\begin{tabular}{lll}
\hline \multicolumn{1}{c}{ Kriteria } & Kategori \\
\hline$X>($ Mean $+S D)$ & Tinggi & \\
$($ Mean $-S D)<X$ & Sedang & \\
$\leq($ Mean $+S D)$ & & \\
$X<($ Mean $-S D)$ & Rendah & \\
\hline
\end{tabular}

Sumber: (Arikunto, 2012)

Teknik analisis statistika inferensial yang digunakan dalam penelitian ini adalah regresi linier sederhana. Sebelum melakukan uji terlebih dahulu melakukan uji prasyarat. Uji prasyarat yang dilakukan adalah sebagai berikut Uji Normalitas, Uji Heteroskedastisitas, dan Uji Linieritas.

\section{Hasil Penelitian dan Pembahasan}

Data Subjective-Well Being siswa SD diperoleh dengan menggunakan angket. Angket yang digunakan terdiri atas 5 Indikator yakni Memiliki perasaan puas dengan kehidupannya secara keseluruhan, Terpenuhinya kebutuhan, keinginan dan harapan dalam hidup, Memiliki sikap optimis, Merasa Bahagia, dan Optimis. Gambaran Subjective-Well Being siswa SD disajikan pada table berikut ini.

Tabel 4 Gambaran Subjective-Well Being Siswa SD

\begin{tabular}{lr}
\hline Statistik & Nilai \\
\hline Jumlah Sampel & 360 \\
Rata-Rata & 91.01 \\
Deviasi Standar & 8.12 \\
Rentang Skor & 52 \\
Minimum & 68 \\
Maximum & 120 \\
\hline
\end{tabular}

Berdasarkan table di atas terlihat bahwa Jumlah sampel yang digunakan untuk memperoleh data Subjective Well Being adalah 360 siswa Sekolah Dasar. Rata-rata respon siswa berkisar pada angka 91.01 dengan deviasi standar 8.12. Rentang skor dari respon siswa tentang Subjective-Well Being adalah 52, dengan nilai maximum dan minimum secara berturutturut adalah 120 dan 68. Hal ini menunjukkan bahwa rata-rata siswa merespon positif setiap pernyataan tentang Subjective Well Being. Sebagian besar diantara mereka setuju bahwa mereka memiliki perasaan puas dengan kehidupan yang diajalani dimasa pandemic saat ini, mereka setuju bahwa kebutuhan, keinginan dan harapan selama belajar dari rumah telah terpenuhi, mereka setuju bahwa mereka masih memiliki sikap optimis untuk sukses belajar dimasa pandemic.

Untuk memperoleh tingkat Subjective-Well Being siswa SD maka peneliti membaginya menjadi tiga kategori yakni tinggi sedang dan tinggi. Adapun tingkat Subjective-Well Being siswa SD disajikan pada table di bawah ini

Tabel 5 Tingkat Subjective-Well Being Siswa SD

\begin{tabular}{lcc}
\hline Kategori & Jumlah & Persentase \\
\hline Tinggi & 53 & 14,72 \\
Sedang & 268 & 74,44 \\
Rendah & 39 & 10,83 \\
\hline
\end{tabular}


Berdasarkan tabel di atas diperoleh bahwa dari 360 siswa SD yang dijadikan sampel terdapat 53 siswa dengan tingkat Subjective-Well Being tinggi, 268 dengan tingkat SubjectiveWell Being Sedang, dan 39 Subjective-Well Being Rendah.

Data Hasil Belajar Matematika siswa SD diperoleh dengan menggunakan tes hasil belajar disajikan pada table berikut ini.

Tabel 6 Hasil Belajar Matematika siswa SD

\begin{tabular}{lr}
\hline Statistik & Nilai \\
\hline Jumlah Sampel & 360 \\
Rata-Rata & 70.17 \\
Deviasi Standar & 15.51 \\
Rentang Skor & 68 \\
Minimum & 32 \\
Maximum & 100 \\
\hline
\end{tabular}

Berdasarkan table di atas tterlihat bahwa Jumlah sampel yang digunakan untuk memperoleh data Hasil Belajar Matematika adalah 360 siswa Sekolah Dasar. Rata-rata Hasil Belajar Matematika siswa adalah 70,17 dengan deviasi standar 15.51. Rentang skor dari Hasil Belajar Matematika siswa adalah 68, dengan nilai maximum dan minimum secara berturutturut adalah 32 dan 100.

Untuk memperoleh tingkat Hasil Belajar Matematika siswa SD maka peneliti membaginya menjadi tiga kategori yakni tinggi sedang dan tinggi. Adapun tingkat Hasil Belajar Matematika siswa SD disajikan pada tabel di bawah ini

Tabel 1 Tingkat Hasil Belajar Matematika siswa SD

\begin{tabular}{lcc}
\hline Kategori & Jumlah & Persentase \\
\hline Tinggi & 66 & 15 \\
Sedang & 234 & 80,83333333 \\
Rendah & 60 & 4,166666667 \\
\hline
\end{tabular}

Berdasarkan hasil analisis data diatas di temukan bahwa Sebagian besar siswa memiliki tingkat subjective well being yang sedang. Terdapat $14,72 \%$ siswa memiliki tingkat subjective well being yang rendah, 74,44\% sedang, dan 10,83\% tinggi.

Data tersebut mengindikasikan bahwa sebagian besar siswa SD memiliki tingkat kepuasan yang baik. Siswa SD merasa bahwa kebutuhan dan keinginan mereka telah terpenuhi khususnya dimasa pandemic covid 19. Mereka merasakan kebahagiaan dalam hidup mereka Ketika melaksanakan pembelajaran meskipun belajar dari rumah serta optimis melalui setiap tantangan di masa sekarang. Selain itu siswa dengan Subjective Well Being pada kategori ini memperlihatkan sikap active dalam proses belajar mengajar.

Hasil penelitian ini menujukkan bahwa indikator subjective well being yang paling dominan diperlihatkan oleh siswa SD adalah Indikator 1 yaitu memiliki perasaan puas dengan kehidupannya secara keseluruhan, indicator 2 yaitu terpenuhinya kebutuhan, keinginan dan harapan dalam hidup, indicator 3 yaitu memiliki sikap optimis, dan indicator 5 yaitu Aktif.

Berdasarkan ketiga uji prsyarat terlihat bahwa seluruh uji asumsi telah terpenuhi yakni uji Normalitas, Linieritas, dan Heteroskedastisitas. Dengan demikian, untuk mengetahui pengaruh Subjective Well Being (X) dengan Hasil Belajar Matematika $(Y)$ dilakukan dengan menggunakan uji regresi linier sederhana.

Analisis Regresi Linier Sederhana digunakan untuk mengetahui hubungan secara linier antara satu variabel independen (X) dan variabel dependen (Y). Analisi ini untuk mengetahui arah hubungan antara variable Subjective Well Being $\left(X_{1}\right)$ dengan Hasil Belajar Matematika $(Y)$. 
Tabel 9 Model of Summary

\begin{tabular}{lcccc}
\hline Model & $\mathrm{R}$ & R Square & Adjusted R Square & $\begin{array}{c}\text { Std. Error of the } \\
\text { Estimate }\end{array}$ \\
\hline 1 & 0.498 & 0.248 & 0.246 & 13.472 \\
\hline
\end{tabular}

Tabel Model of Summary untuk Hipotesis 1 memperlihatkan bahwa nilai R adalah 0,498 artinya adalah hubungan kedua variabel penelitian berada pada kategori cukup. Nilai R Square atau koefisien Determinasi (KD) yang menunjukkan seberapa baik model regresi yang tercipta dari hubungan Subjective Well Being $\left(X_{1}\right)$ dengan Hasil Belajar Matematika $(Y)$. Nilai Koefisien Determinasi yang diperoleh adalah $0,248 \times 100 \%=24,8 \%$. Sehingga dapat nyatakan bahwa variabel bebas Subjective Well Being $\left(X_{1}\right)$ memiliki pengaruh kontribusi sebesar $24.8 \%$ terhadap Hasil Belajar Matematika $(Y)$.

Tabel 10 Hasil Uji Anova

\begin{tabular}{llrrrrr}
\hline Model & & Sum of Squares & Df & Mean Square & \multicolumn{1}{c}{ F } & \multicolumn{1}{c}{ Sig. } \\
\hline 1 & Regression & 21444.535 & 1 & 21444.535 & 118.151 & $.000^{\mathrm{b}}$ \\
& Residual & 64977.465 & 358 & 181.501 & & \\
& Total & 86422.000 & 359 & & &
\end{tabular}

a. Dependent Variable: Hasil_Belajar_Matematika

b. Predictors: (Constant), Subjective_Well_Being

Berdasarkan Hasil Uji Anova untuk Hipotesis 1 di atas terlihat bahwa nilai signifikansi adalah 0,001 yang lebih kecil atau sama dengan 0,05. Artinya adalah model regresi yang diahasilkan dapat digunakan untuk memprediksi cariabel hasil belajar matematika siswa (Y).

Tabel 11 Output Coefficient

\begin{tabular}{|c|c|c|c|c|c|c|}
\hline \multirow{2}{*}{\multicolumn{2}{|c|}{ Model }} & \multicolumn{2}{|c|}{$\begin{array}{c}\text { Unstandardized } \\
\text { Coefficients }\end{array}$} & \multirow{2}{*}{$\begin{array}{c}\text { Standardized } \\
\text { Coefficients } \\
\text { Beta } \\
\end{array}$} & \multirow[b]{2}{*}{$\mathrm{t}$} & \multirow[b]{2}{*}{ Sig. } \\
\hline & & $\mathrm{B}$ & Std. Error & & & \\
\hline \multirow[t]{2}{*}{1} & (Constant) & -16.795 & 8.032 & & -2.091 & .037 \\
\hline & Subjective_Well_Being & .957 & .088 & .498 & 10.870 & .000 \\
\hline & oendent Variable: Hasil_B & r_Matem & tika & & & \\
\hline
\end{tabular}

Berdasarkan table di atas terlihat bahwa pada kolom b baris constant nilainya -16,765 dan nilai subjective well being adalah 0,957 . Dengan demikian persamaan regresi yang tercipta adalah

$$
Y=-16,765+0,957 X
$$

Pada table diatas juga terlihat bahwa nilai t adalah 10,870 dengan taraf signifikansi $0,000 \leq 0,05$ yang berarti $H_{0}$ ditolak. Dengan demikian dapat kita simpulkan bahwa terdapat Pengaruh Subjective Well Being terhadap Hasil Belajar Matematika Siswa Sekolah Dasardimasa Pandemi Covid-19.

Hasil penelitian diatas memperlihatkan bahwa terdapat pengaruh Subjective Well Being terhadap hasil belajar matematika siswa Sekolah Dasardimasa Pandemi Covid-19. Hal tersebut selajalan dengan pendapat (Zakiyah, 2020) bahwa hubungan yang signifikan antara subjective well-being siswa dengan hasil belajar, siswa yang memiliki Subjective Well Being yang tinggi akan memiliki semangat dalam menjalani hidupnya, namun sebaliknya jika individu atau siswa yang memiliki Subjective Well Being yang rendah maka siswa itu tidak memiliki semangat hidup, namun hidupnya penuh dengan rasa emosi yang rendah dan tidak dapat dikendalikan. 
Setiap indikator memiliki rerata disekitaran angka 3. Artinya adalah Sebagian besar siswa Memiliki perasaan puas dengan kehidupannya secara keseluruhan, Selain itu siswa merasa bahwa kebutuhan, keinginan dan harapan dalam hidupnya telah terpenuhi. Siswa SD dapat di simpulkan memiliki sikap optimis terhadap meskipun belajar dimasa pandemic covid 19. Namun demikian dari aspek kebahagiaan, siswa SD masih cenderung kurang. Dari segi keaktifan siswa, mereka cenderung aktif saat melakukan pembelajaran.

Secara keseluruhan tingkat Subjective Well being Siswa SD berada pada ketegori sedang sampai tinggi. Dikaitkan dengan hasil belajar, Sebagian besar siswa SD memiliki rata-rata hasil belajar berada pada kategori sedang sampai tinggi. Data tersebut mengindikasikan bahwa semakin tinggi Subjective Well Being siswa maka hasil belajar matematikanya pun semakin tinggi.

Sejalan dengan Penelitian Abele (Wijayanti, Pebriani \& Yudiana, 2019) yang memperlihatkan bahwa Subjective Well Being yang tinggi memiliki pengaruh yang baik pada kinerja kognitif peserta didik. Hal ini juga sejalan dengan pendapat Berger (O' Connor, 2013) menemukan bahwa kualitas hidup sesorang akan meningkat sejalan dengan menurunnya kesenjangan antara tujuan yang telah dicapai dengan tujuan yang ingin di capai oleh seseorang tersebut.

Siswa yang memiliki perasaan puas dengan kehidupannya, terpenuhi kebutuhannya, optimis, dan Aktif akan cenderung memiliki hasil belajar yang baik. Sejalan dengan pendapat (Wijayanti, Pebriani, \& Yudiana, 2019) bahwa Subjective Well Being akan berpengaruh pada prestasi akademik yang lebih baik dan kreativitas yang lebih tinggi.

Dengan demikian setiap siswa sangat penting untuk memiliki subjective well-being yang tinggi, karena siswa yang meimiliki subjective well being yang tinggi akan cenderung memiliki persaaan atau pikiran positif sehingga segala permasalahan hidup khususnya dimasa pandemic covid-19 dan tugas tugas sekolah yang diperoleh dapat terselesaikan dengan baik.

\section{Kesimpulan dan Saran}

Berdasarkan hasil analisis dan pembahasan yang telah dilakukan, maka peneliti menarik kesimpulan sebagai berikut:

1. Subjective Well Being siswa Sekolah Dasardimasa pandemi Covid-19 berada pada kategori sedang dimana indicator yang paling mendominasi adalah memiliki perasaan puas dengan kehidupannya secara keseluruhan, terpenuhinya kebutuhan, keinginan dan harapan dalam hidup, memiliki sikap optimis, dan aktif.

2. Terdapat pengaruh Subjective Well Being terhadap Hasil Belajar Matematika siswa Sekolah Dasar dimasa pandemi Covid-19.

\section{DAFTAR PUSTAKA}

Arikunto, S. (2012). Prosedur Penelitian Suatu Pendekatan Praktek. Jakarta: Rineka Cipta.

Compton, W. C. (2000). Meaningfulness as a mediator of Subjective Well Being. Psychological reports, 87(1), 156-160.

Diener, E. (2000). Subjective Well-Being The Science of Happiness and a Proposal for a National Index. American Psychological Association Vol.LV (1), 34.

Fauzi, I., \& Khusuma, I. H. S. (2020). Teachers' Elementary School In Online Learning Of Covid-19 Pandemic Conditions. Jurnal Iqra’: Kajian Ilmu Pendidikan, 5(1), 58-70. 
Froh, J. J., Franklin, B., \& Templeton, J. (2009). Happiness. The Encyclopedia Of Positive Psychology, 1, 455-461.

Hudaifah, F. (2020). The Role of Self Regulated Learning in The Covid-19 Pandemic Era. Biormatika: Jurnal ilmiah fakultas keguruan dan ilmu andemic n, 6(02), 76-84.

Maddux, J. E. (2018). Subjective Well Being and life satisfaction: An introduction to conceptions, theories, and measures. Routledge/Taylor \& Francis Group

O'Connor, R. (1993). Issues in the measurement of health related quality of life. Australia.

Ramadhani, D. (2017). Efektivitas Bimbingan Gratitude Untuk Meningkatkan Subjective Well Being Peserta Didik (Doctoral dissertation, Universitas Pendidikan Indonesia).

Shoshani, A., \& Steinmetz, S. (2014). Positive psychology at school: A school-based intervention to promote adolescents' mental health and well-being. Journal of Happiness Studies, 15(6), 1289-1311.

Silvia, A. R. (2018). Efektivitas Teknik Coaching Untuk Peningkatan Psychological WellBeing Siswa (Doctoral dissertation, Universitas Pendidikan Indonesia).

Wijayanti, P. A. K., Pebriani, L. V., \& Yudiana, W. (2019). Peningkatan Subjective Well-Being In School Pada Siswa Melalui "Peer Support And Teaching Method Program". Journal of Psychological Science and Profession, 3(1), 31-42.

Zakiyah, Z. (2020). Hubungan Antara Subjective Well Being Dengan Hasil Belajar Biologi Siswa Kelas X Sma Nuraida Islamic Boarding School (NIBS) Bogor. Jurnal Teknologi Pendidikan, 9(1). 